Tidsskrift for familierett, arverett og barnevernrettslige spørsmål (FAB) 2005 - Nr 04 - "Farsrettigheter og mødres handlingsrom" av Margunn Bjørnholt

Side 259:

\title{
Farsrettigheter og mødres handlingsrom
}

\author{
Av Margunn Bjørnholt
}

Margunn Bjørnholt, f. 1958, magister i sosiologi, tidligere forsker ved Arbeidsforskningsinstituttet, nå selvstendig, blant annet med prosjekter innen familie og likestilling. Hun underviser i familie og likestilling ved Institutt for sosiologi, Universitetet i Oslo.

Hvordan opplever mødre sitt morskap i lys av økte fedrerettigheter og en sterk farsretorikk? Mens fedre er aktive og synlige padrivere for reformer innen familieomradet, er mødrenes interesser og stemmer $i$ liten grad fremme $i$ offentlig debatt og meningsdannelse. Denne artikkelen setter fokus på mødres erfaringer og opplevde handlingsrom i saker der det er rettslig konflikt om daglig omsorg og samvær.

\section{Farsrettigheter og farsretorikk på fremmarsj}

De krenkede fedrenes agenda har lenge satt dagsorden, og beveget meningsdannelse og lovgivning i fedrenes retning. Det er bred forståelse for fedrenes krav om å få «ta mer omsorg» for sine barn. Fedrerettsbevegelsen kan her ta i bruk samfunnsmessige forestillinger det er bred enighet om, som likestilling og forestillinger om barnets beste. Både i Norge og internasjonalt bruker fedrerettighetsgrupper media aktivt, og en engelsk fedrerettighetsorganisasjon har gjentatte ganger lykkes i å få internasjonal oppmerksomhet om sine stuntaksjoner, ved blant annet å klatre opp på fasader ikledd ulike varianter av supermannkostymer. ${ }^{2}$ Retorikken er den samme fra land til land; alt fedrene ønsker er å få være superpappaer for sine barn.

Fedregrupper verden over er flittige leverandører av lovforslag og høringsnotater med betydelig gjennomslag de siste årene. I Norge har blant annet bidragsreglene blitt endret etter påtrykk fra fedregrupper, og reglene om farskap er endret, ved at tidligere tidsfrist for å reise farskapsssak er fjernet. Det samme er kravet til mors samtykke. ${ }^{3}$ Barnelovgivningen bygger, ifølge Haugli på en tiltakende rettighetsideologi, der særlig farsrettigheter er i vinden. ${ }^{4}$

Farsrettighetsdiskursen bygger dels på en aktiv bruk av likestillingsbegrepet - fedre vil bli likestilt med mødre som foreldre. Et viktig element er også en negativ fremstilling av mødre/ekspartnere. Boyd ${ }^{5}$ mener demonisering av mødre er en viktig del

1. Artikkelen bygger på et «paper» som ble fremlagt på sluttkonferansen for det nordiske forskningsprogrammet Kjønn og vold 10.-12. juni 2005.

2. Se f.eks. Dagbladet 28.01.2005.

3. Se Lødrup 2003.

4. Haugli 2004: 349. 


\section{Side 260:}

av fedrerettighetsbevegelsens retorikk. ${ }^{6}$ Gjennom medieoppslag tas det rutinemessig stilling for fedrene. Fedre fremstår som entydig gode og fedres kamp som rettferdig i lys av forestillinger om urimelige mødre. Ofte deltar forskere i et samrøre med farsdiskursen som underliggende premiss. I et intervju med Dagsavisen uttaler for eksempel den kjente familieforskeren Frode Thuen: ${ }^{7}$

Utviklingen mot foreldrelikestilling (kunne) allerede ha kommet mye lenger hvis det ikke hadde vært for ett forhold: Mors motvilje mot å la far slippe til. - Ofte er det nødvendig med en rettssak før barna får anledning til å bo hos far, konstaterer Thuen.

Det er ikke alltid så lett å oppgi privilegier, og det å ha en dominerende posisjon overfor barna, er et av de få privilegiene kvinner alltid har hatt. Ved samlivsbrudd forventer mødre fortsatt på en måte at det er de som skal bestemme hvor barna skal bo. Hvis far vil at barna skal bo hos ham eller ønsker delt omsorg, er det derfor ofte duket for konflikt, utdyper han.

Her tilskrives mødrene privilegier, makt og dominans, mens far «ønsker delt omsorg». At mødrene kunne handle ut fra annet enn illegitim egeninteresse og at fedrene kunne handle utfra andre motiver enn det aktverdige å få ta mer omsorg for sine barn, utelukkes. Spørsmålet om fordeling av omsorgsansvar og -arbeid før samlivsbruddet berøres ikke - her vet vi at kvinner fortsatt i all hovedsak har hovedansvaret. ${ }^{8}$ Ved samlivsbrudd nulles imidlertid tidligere foreldrepraksis ut, og barna behandles som et gode som skal fordeles rettferdig mellom foreldre. Etter mitt syn må det være dypt problematisk dersom fedre som har daglig omsorg, i stor grad har fått det etter rettssak, ettersom mye tyder på at fedre som involverer seg i rettslige konflikter generelt er overrepresentert når det gjelder vold og overgrep. ${ }^{9}$ Vold og overgrep synes også å forsvinne i rettsapparatet - Skjørten fant at far fikk omsorgen i 50 $\%$ av sakene, uavhengig av eventuelle vold- og overgrepsmistanker som inngikk i $23 \%$ av sakene. ${ }^{10}$ Haugli fant at far fikk gjennomslag i $59 \%$ av sakene i $2002 .{ }^{11}$

6. At morsfiendtlighet også er en del av de norske fedrenes rettighetskamp, tyder følgende på: Aftenpostens faste samlivsspaltist Sissel Gran ser seg den 20.02.2005 nødsaget til å legge ut følgende advarsel til spaltens innsendere: «Innspill av typen: «Til kamp mot kjerringer som bruker ungene mot oss! Og nulltoleranse for farsboykott!», făr ikke spalteplass her. Dere kan slutte å skrive. Mer krig er ikke denne psykologens anliggende.»

\section{Dagsavisen 02.05.2004.}

8. Kitterød 2002.

9. Hester 2002 .

10. Skjørten 2002.

11. Haugli 2004. 


\section{Tause mødre}

I et av de mange TV-programmene der fedre sto frem med sine saker om mødre som angivelig nektet dem å se barna sine, ble det opplyst at programlederen også hadde kontaktet mødrene, som ikke ville stille opp. Dette fungerte i sammenhengen som en bekreftelse på hvor urimelige de var. Mødrenes situasjon er her helt ulik fedrenes. Ettersom mødrene ofte har omsorgen, vil det å diskutere en konflikt om daglig omsorg og samvær på TV være vanskelig og lite ønskelig, både utfra hensynet til barna og til dem selv, og de har mye å tape og lite å vinne på å delta. Dette fører til at konfliktorienterte og krenkede fedre uimotsagt făr fremføre sin sak i offentligheten, mens mødrene forholder seg tause av hensyn til barna og seg selv. Mødrene får dermed heller ikke den offentlige sympati man kan få gjennom å legge frem sin sak.

Det er få eller ingen som taler mødrenes sak i offentligheten. Flere forhold kan bidra til det. Betydningen av morskapet har gjennom flere tiår blitt nedtonet i likestillingens navn, i et fors $\varnothing \mathrm{k}$ på å befri kvinner fra kjønn som skjebne og sette kvinner fri til å være mer enn mødre. Nedtoningen av morskapet har gått så langt at selve forestillingen om den gode mor er forsvunnet fra offenligheten, ifølge Ladd-Taylor som fant at det var den dårlige mor som dominerte mediebildet. ${ }^{12}$ Den gode mor syntes helt forsvunnet. Hånd i hånd med nedtoningen av morskapet har man i økende grad vektlagt behovet for at far skal ta en større del av omsorgsarbeidet. Veien har imidlertid gått gjennom å forskuttere rettigheter, mens det ikke har skjedd noen skjerping av fedres plikter og ansvar.

Endelig synes det som om mødres troverdighet som legitime forvaltere av barnets beste er generelt svekket innen hjelpeapparatet, såvel som innen rettvesenet. ${ }^{13}$ Styrkede farsrettigheter er særlig tydelige i forhold til samvær etter foreldrebrudd. Retten til samvær står så sterkt at kvinner i dag har vanskelig for å beskytte barn ved mistanke om overgrep. Kvinner blir stående i en umulig situasjon: om de hindrer samvær med en overgrepsmistenkt far risikerer de å miste daglig omsorg til samme far. Likevel er det mors ansvar å sikre at barnet ikke blir utsatt for overgrep. Det kan synes som om man i løpet av 1990-årene har gått fra en «føre-var»-politikk med begrensninger og tiltak i forhold til samvær ved (oftest mors) mistanke om overgrep, til en rettighetsorientert praksis, der fars rett til samvær veier tyngre enn faren for overgrep. ${ }^{14}$ I praksis viser det seg at mange saker om samvær og

12. Ladd-Taylor 2004.

13. På et møte om mødre til ofre for seksuelle overgrep ved Universitet i Oslo våren 2004 ble det også påpekt av flere ansatte ved krisesentre og sosialkontorer at det verste var om det var mor som hadde mistanke. De var fullt klar over at hun ikke ville bli trodd, og prøvde å finne andre som kunne bekrefte mistanken for å ha håp om å vinne frem med tiltak for å beskytte barnet.

14. Hester 2002 har dokumentert denne utviklingen for Danmark.

Side 262: 
daglig omsorg som kommer til rettsapparatet er skjulte

overgrepssaker ${ }^{15}$ men overgrep kommer i bakgrunnen, og det blir mors mistanke, ikke fars eventuelle overgrep, som blir problemet. Radford og Tsutsumi viser at diskursen om likestilt foreldreskap, globalisering av relasjoner og økte fedrerettigheter har ført til mer vold mot kvinner og barn. ${ }^{16}$ Barne- og familieministeren har imidlertid grepet fatt i samværsproblematikken, og har foreslătt en presisering av barneloven for å kunne hindre samvær som er til skade for barnet. ${ }^{17}$

Hittil har man i hjelpeapparatet skilt skarpt mellom den voldelige mannen og hans farskap, ${ }^{18}$ og man har vært opptatt av å fremme kontakt mellom far og barn. I tillegg til likestillingsdiskursen er farsbehov- eller farsfraværsdiskursen en viktig bakgrunn for å forstå kraften i krav om økte fedrerettigheter og tilsvarende krymping av mødrene. Den negative effekten av farsfravær har vært et viktig argument for økte rettigheter for fedrene, både i forbindelse med fødsel og omsorg for små barn, og i forbindelse med samlivsbrudd. Barns rett til to foreldre, og fedres betydning for barn har blitt alment akseptert som en ubestridt sannhet. Utfra denne tenkningen tilstreber for eksempel hjelpeapparatet kontakt mellom voldelige fedre og barn. Keskinen fant at selv der barnet var redd for faren, og selv der faren ikke var interessert, presset hjelpeapparatet på for å fă istand samvær. ${ }^{19} \mathrm{Et}$ norsk prosjekt for voldelige fedre begrunnes også med argumenter fra farsbehovsdiskursen: «Også barn av menn som har truet og slått kvinner trenger faren sin» heter det i omtalen av prosjektet i Aftenposten. ${ }^{20}$

Behovet for menn i barnehager støtter seg også på farsbehovsdiskursen, der menn tilskrives en særlig betydning $\mathrm{i}$ sosialiseringen, særlig for gutter, og Barne- og familiedepartementet har lenge hatt et eget prosjekt for å få flere menn inn i barnehager. ${ }^{21}$ Det er imidlertid i dag bred faglig enighet om at farsfraværshypotesen ikke støttes av forskning. ${ }^{22}$ Dette er derfor også et eksempel på etterslepet mellom forskningsfronten og folkelig/praksisnær kunnskap som grunnlag for institusjonalisert praksis. ${ }^{23}$

15. Eriksson 2003, Skjørten 2002 og 2004.

16. Radford og Tsutsumi 2004.

17. I tråd med det som ble signalisert i Familiemeldingen, 2003, og rapport fra en arbeidsgruppe om vold mot kvinner, 2004.

18. Keskinen 2002 og Eriksson 2002 og 2003.

19. Keskinen 2002

20. Aftenposten 19.01.2004

21. At en del av de menn som rekrutteres til barnehagene er menn med betydelige tilpasningsproblemer i forhold til arbeidslivet og rusproblematikk, og hva slags «rollemodeller» disse utgjør, har i liten grad blitt problematisert.

22. Hjorth og Bagøe-Nielsen 2003 foretar både en bred gjennomgang av denne forskningen, og en kritisk drøfting av de siste ti årenes innsats for å få flere menn i barnehager.

23. Dette er ikke noe særsyn for dette feltet. Weiser-Aall 1973 s. 19 skriver at norske «bygdedoktorer» helt inn i midten av 1800-tallet brukte medisinske skrifter fra 1500-1700-tallet som oppslagsverk. Disse bygde igjen ofte på sammenskrivning av eldre verker helt tilbake til 200-tallet e.Kr. 
I den senere tiden er man imidlertid på vei mot en forståelse av vold mot partner som et problem som også berører

foreldreskapet, ${ }^{24}$ og at det å være vitne til vold mot mor er psykisk vold mot barn. Dette tyder på en større politisk vilje til å ta vold på alvor. Samtidig er det en fare for at det fører til en rangering av vold, der bare den groveste fysiske volden gir grunnlag for tiltak. Kvinner som har levd $\mathrm{i}$ voldelige forhold sier selv at det ikke er den fysiske volden som er den verste, men den psykiske. ${ }^{25}$ Mellberg er opptatt av den begrensning av kvinners livsrom som (potensielt) voldelige menn utøver. Hun argumenterer for å fokusere på begrensningen av livsrommet, heller enn bare å fokusere på den fysiske volden.

At mødre saboterer samvær er etablert som en folkelig sannhet, til tross for at det ikke har lykkes forskningsmessig å belegge denne påstanden. Tvert om synes mødre å strekke seg langt for å ivareta barnas relasjon med far etter samlivsbrudd. ${ }^{26}$ Samtidig er det fortsatt mødrene som i stor grad står for daglig omsorg og ivaretar barnas daglige behov, herunder relasjonen til far, også i situasjoner der de er i alvorlig konflikt med far.

\section{Mødre i skyggen av farsdiskurs og rettsaker}

Utgangspunktet er at fedre og fedreperspektiv i stor grad har preget debatt, meningsdannelse og senere tids lovendringer på foreldreområdet, mens mødrenes stemme i liten grad har kommet frem. Artikkelen bygger på dybdeintervjuer med mødre som nylig har vært i rettslige konflikter med barnefar om daglig omsorg eller samvær. Jeg legger opp til en informantnær analyse, der hensikten er å bryte tausheten og la mødrene komme til orde om det å være mor i rettslig konflikt med eksmann, herunder møtet med hjelpeapparat og rettsvesen. Deretter vil jeg analysere i hvilken grad disse mødrenes erfaringer kan si noe om mødres handlingsrom og muligheter for mestring, og hvordan rettvesen og hjelpeapparat ivaretar kvinner som mødre og omsorgspersoner for sine barn.

Mens dette skrives, og med intervjuene det bygger på friskt $\mathrm{i}$ minne, leser jeg et innlegg av en mor i spalten til samlivseksperten og psykologen Sissel Gran i Aftenposten. ${ }^{27}$ Denne moren har valgt å la barnet bo hos far, og har selv vanlig besøksordning, noe hun begrunner med at faren bodde på et sted der det ville bli van-

24. Dette gjenspeiles blant annet i arbeidet til Kvinnevoldsutvalget (NOU 2003: 31).

25. Mellberg 2005.

26. Kaul 2001 og 2003.

27. Aftenposten 27.02.2005.

\section{Side 264:}

skelig for henne å finansiere ny bolig. Dessuten ville mannen ikke skilles og ville heller ikke at sønnen skulle bo hos henne. «Etter nøye overveielse fant vi at det beste for sønnen vår, var a bo med sin far» skriver hun, men gir samtidig uttrykk for at «Det var ingen lett heslutnina. Oa hver daa har vart nreaet av savn.» Denne. 
argumentasjonen sier mye om kvinners endrede handlingsrom som mødre, blant annet økonomisk, der individuell selvforsørging som norm fører til at kvinner ved samlivsbrudd står mye svakere enn for bare få år siden, da menn i større grad hadde plikt til å sørge for ikke bare barna, men også for mor og barn gjennom hustrubidrag, noe som idag nærmest er avskaffet. Når kvinner fortsatt tjener mindre enn menn, i tillegg til at kvinner oftere har hatt fravær og deltid $\mathrm{i}$ arbeidslivet på grunn av omsorg, rammes kvinner hardt ved samlivsbrudd når foreldrene vurderes som enkeltstående og selvforsørgende personer, der forsørgerevnen (for eksempel råd til å bli boende i felles bolig) også kan bli et argument for hvem som er best skikket til å ha omsorgen for barnet. Den salomoisk-kloke beslutningen om å la far få sin vilje, uten å tematisere eventuelle egne ønsker og behov, vitner også om en avmakt utover det rent økonomiske, og blir først meningsfull i lys av hva som eventuelt kunne blitt alternativet.

To kvinner og mødre som i utgangspunktet valgte helt forskjellig da de tok initiativ til skilsmisse fra mannen, har stilt sine erfaringer til rådighet: Britt $^{28}$ krevde og har hele tiden hatt daglig omsorg for sine to barn, mens faren har utvidet samvær. Faren fører stadige rettsaker om daglig omsorg, bidrag m.m. Ellen lot barna bli hos faren i det lille lokalsamfunnet de bodde, og flyttet selv til en større by, betalte bidrag og hadde vanlig samvær. Hun har tatt initiativ til to rettssaker for å få daglig omsorg etter det hun opplevde som omsorgssvikt hos faren.

\section{Britt - et liv med daglig omsorg og stadige rettssaker}

Britt skilte seg fra mannen som hadde forandret seg etter at de fikk sitt andre barn:

Han var aggressiv og sinna på en på en unaturlig måte, som jeg ikke har opplevd at voksne mennesker ... jeg opplevde at det var noe i veien - noe alvorlig i veien. Så var det sånn at han skulle ikke bruke penger, han skulle ikke bruke penger på barna, ingen i det hele tatt. Vi skulle kjøpe på loppemarked og han var veldig ... gikk gjennom kvitteringer i timevis og holdt på sånn. Veldig

kontrollerende ... Og den enkelte episoden som gjorde at jeg tok kontakt med familierådgivningskontoret med en gang, var da han låste inn sønnen vår på rommet sitt da han skulle sove - han sov ikke om natten sønnen vår - så han låste ham

28. Informantene er anonymisert.

\section{Side 265:}

inne på rommet. Og da reagerte jeg med sinne og gråt og fortvilelse, og det reagerte han ikke på, da gjemte han nøkkelen isteden.

Etter denne episoden tok hun kontakt med familierådgivningskontoret, hvor de gikk trekvart år, og hvor hun ikke opplevde at de tok problemene på alvor. Britt fikk daglig omsorg etter et hastevedtak da eksmannen kidnappet datteren etter at hun flyttet fra ham med de to barna.

Siden skilsmissen, som det nå er flere år siden, har mannen ført aientatte rettcsaker. der han krever daalia nmsnra. men hun har 
fătt medhold hver gang. Hun hadde vært hjemme med begge barna. Utfra den situasjonen hun var i, opplevde hun de senere rettssakene, der han anket, som ydmykende:

Da var jenta vår tre år sønnen fem år og jeg hadde vært hjemme i to år med jenta vår og vært hjemme i tre år med gutten ... Og situasjonen var som den var. Og alikevel skal du måtte møte i retten og på en måte forsvare at det er til barnas beste at de fortsetter å bo hos deg.

Hun opplevde ikke at det hun opplever som mannens alvorlige psykiske problemer og den skade han påfører både barna og henne gjennom sine handlinger, har blitt sett eller tatt på alvor, hverken $\mathrm{i}$ familierådgivning, der hun først henvendte seg, eller i flere av rettsakene.

Jeg mener det er noe alvorlig i veien med eksmannen min. Og når det er noe alvorlig i veien, så klarer de ikke å ta tak i det, tar ikke det på alvor.

Hun opplever at hun fikk barna utfra en vilkårlig og overfladisk vurdering:

Så det som står i dommen er at jeg har vært hjemme med henne så mye og antakelig er barna mest knyttet til meg og det er naturlig at jeg har daglig omsorg. Ja og at jeg har tilfredsstillende bolig og noe sånt ... Så jeg tenker at hvis jeg ikke hadde vært hjemme med dem i den situasjonen ... hva hadde skjedd da?

Hun har fortsatt daglig omsorg, mens han har utvidet samvær. I tillegg til rettssakene om barna fører han rettssaker om delingen av boet og om bidrag. Han har også brukt media svært aktivt, og flere ganger stått frem i ulike medier sammen med barna under fullt navn. Det har blitt pătalt av retten at han har gått ut i media med barna, og at han ikke later til å kunne sette barnas beste foran sitt eget, men det har ikke fătt noen konsekvens, og han har fortsatt med det.

Allerede før samlivsbruddet fikk mannen problemer med konflikter på jobben, han har etterhvert gått fra sykmelding og over på trygd, og betaler lite bidrag. Han gikk en periode ned i halv stilling, noe han begrunnet med at han skulle ta seg mer av barna. Men barna bor fast hos mor, og dette ble derfor ikke akseptert av trygdekontoret. Dette fører han fortsatt rettssak om overfor tryg-

\section{Side 266:}

dekontoret/staten. Det fastsatte bidraget er lite, og ifølge Britt har han for det meste ikke betalt. Med de nye bidragsreglene, der bidragsevne, samvær og mors inntekt skal regnes med i utregningen av bidraget, har bidraget krympet til et minimum. Britt er derfor i praksis eneforsørger for barna.

Han har gjentatte ganger gått til sak for å få daglig omsorg for barna, og hun har nå seks dommer for at hun skal ha omsorgen. Til tross for at hun har fått daglig omsorg hver gang, og mannens krav er blitt avvist, har han lykkes i å få saken opp gang på gang. De mange rettsakene er en stor økonomisk belastning for henne, og til tross for en normalt and stillina er hun avhenaia av aknnomisk hieln 
fra familien. Mannen har på grunn av sin lave inntekt rett til fri rettshjelp, og rettsakene er dermed ingen økonomisk belastning for ham. Ettersom han ikke arbeider er kampen om barna også mer eller mindre en heltidsbeskjeftigelse for ham, og han engasjerer seg ikke bare i egen sak, men også i fedresaken generelt. Hun ser for seg at han kommer til å fortsette med dette, og hun må leve med omkostningene:

Men nå er det mer sånn at jeg får sånn evig dårlig økonomi antakelig, hele livet, ... og mine valgmuligheter er så små, jeg må stadig møte i retten.

Hun har store utgifter til advokat, og sier at:

Det hadde jeg ikke klart uten familien min. Og det er helt tilfeldig at de kan hjelpe meg. Det trengte ikke vært sănn, da ... vet jeg ikke hvordan ting hadde gått. Da hadde jeg kanskje ikke hatt et ordentlig sted å bo, da hadde jeg kanskje bare måttet tenke at hvis du går til sak, så fắr du bare ta dem, for det kan jeg ikke. Nei da, vet du hva, da hadde jeg ikke levd ... Når du er avhengig av rettsvesenet, så er du også avhengig av penger.

De mange rettsakene er ikke bare kostbare, men også utmattende for Britt. Hun har vært syk en periode, og er redd for å bli syk igjen, ettersom hun opplever at hun er den eneste av foreldrene som fungerer og som har en inntekt. Hun er forundret og oppgitt over at eksmannen skal få lov å trekke henne inn i gjentatte rettssaker og påføre henne nye omkostninger og belastninger uten at det er nye momenter i saken:

Det tillates at den som har behov for å krangle på alt, den kan kjøre den andre forelderen i senk, og er det riktig? Og i det gode formåls tjeneste tilsynelatende, for du vil jo bare være en god far for dine barn. Men altså når du går til rettssak nummer seks, så mener jeg at dommeren bare burde si at dette er ikke til barnas beste å ha en ny krangel om det og ferdig med det, vi kan alle gå hjem. Ferdig. Istedet så blir barna hørt og ... og det blir på nytt og ...

Hans rettssaker styrer og vanskeliggjør hennes liv:

Når han setter igang noe, så blir jeg også dratt inn i det. Det er vanskelig nok å fungere som aleneforelder, men du skal i tillegg forholde deg

\section{Side 267:}

til noen som spenner bein på deg hele tiden ... Og du får ingen hjelp. Du må bare stille opp på de premisssene der hele tiden.

Hun opplever at økte fedrettigheter innsnevrer mødrenes handlingsrom:

Så han er grenseløs synes jeg og i forhold til det å fighte og fighte og fighte på bekostning av barna og på bekostning av meg. For jeg synes noen bør ... hvordan skal du stoppe en far? Du gir mange rettigheter til fedre for å oppmuntre fedre og det er bra, men alle ordninger kan bli misbrukt og det virker som om ingen har tenkt på hva som skjer ... For hundre ... år siden så tror jeg det var sånn at mødre når dı aikk fra mannen din. så kunne dı kanskie knmme. 
deg ut av døra, men du må ikke tro at du fikk med deg ungene dine eller du fikk med deg eller noe som helst. Nå er vi der igjen at hvis ikke du får med deg mannen din på en dialog eller fornuftige ting, så stiller du dårlig og det er et tankekors, for du skal igjennom så mye rart og det er egentlig på grensen til hva man klarer og man orker egentlig ikke. Men han kan liksom holde på og holde på og holde på. Kan til og med bruke barna. Jeg forstår ikke det.

Forholdet til rettsvesenet er dobbelt: dels er hun helt avhengig av rettssystemet for å få på plass avtaler om barna, og hun har også fătt medhold i samtlige rettsaker om daglig omsorg som han har reist. Dels er rettsvesenet en ressurs for ham, som han kan bruke til å styre hennes liv gjennom å påføre henne stadig nye runder og de personlige og økonomiske belastningene det medfører.

Hun savner en forståelse for hvordan mødre som har barn med de mest konfliktorienterte fedrene har det:

Men hvilken ydmykelse av mødre som har barn med fedre som er av den - hva skal jeg si - harde kjerne av - jeg kaller det krigshissere, jeg. Den ydmykelsen der, den er det ingen som har tatt fatt i. Og det der med at du ønsker far velkommen og at du trenger aktive fedre og alt det der, det er en god debatt, men i den debatten der har det blitt helt borte at vi som sliter med fedre som sliter, for å si det på den måten, vi sliter enormt.

Når han bryter avtaler og for eksempel henter barna utenom avtalt tid eller ikke leverer dem etter samvær, opplever hun at det ikke er noen instans å henvende seg til, og at han i praksis kan ta seg til rette som han vil. Hun har forsøkt å få barnevernet til å bistå, men de har hittil ikke villet bidra til håndhevingen av avtalene. Hun opplever seg som maktesløs:

Det er makta som rår da. Det blir jo det. Når ikke dommer etterleves og ingen kan gjøre noe. Jeg har altså en dom, seks dommer, da han startet med dette i fjor, seks dommer, og alikevel er det ingen som kan hjelpe deg når den blir brutt. Politiet vil ikke gjøre noen ting, barnevernet vil ikke gjøre noen ting. Du har så mange dommer og likevel hjelper det deg ingenting. Det var et kjempesjokk. For jeg har ikke noe valg. Men jeg har ihvertfall hatt en form for beskyttelse eller kall det hva du vil,

\section{Side 268:}

fordi at det har vært en dom, men nå følger han ikke den heller. Da har jeg ingenting.

Han trekker stadig barna inn i konflikten, og hun bruker mye tid og anstrenger seg for å hjelpe barna å bearbeide ting han har sagt mens de var hos ham. Hun engster seg for hvordan barna har det med at han stadig forteller dem at det er urettferdig at de ikke bor like mye hos ham, og når han går ut i media sammen med barna. Hun engster seg $i$ forbindelse med samvær når han ikke leverer barna tilbake og når han henter barna fra skole uten at det er avtalt og beholder dem. Hun er også bekymret for kvaliteten på omsorgen, særlig etterhvert som barna blir større og «krever mer voksne svar». Hun er også redd for at han i enda større grad vil bruke barna og manipulere dem for å få dem til å ville bo hos ham. Han har saat nå meklina at når sønnen hlir 1). så kan han 
bestemme selv, og da skal han bo hos far, og kommer aldri til å ville se mor. Selv er han meget isolert og er også i konflikt med egen familie. Barna treffer bare hans familie hjemme hos henne. «Han er en kriger», sier hun om eksmannen. Til tross for belastningene som han påfører henne, prøver hun likevel a opprettholde et godt bilde av ham overfor barna.

\section{Ellen - fra fjernomsorg til kamp om daglig omsorg}

Ellen flyttet fra mannen da hun opplevde at han ikke var villig til å innrette livet etter at de hadde fătt fire barn på åtte år. Mannen fortsatte som før med sine fritidsaktiviteter og overlot alt til henne. To ganger var han også voldelig, og kastet henne gjennom rommet mens barna så på. Hun var nedbrutt og utslitt og opplevde at hun måtte bort.

Ellen lot de fire barna bli hos far på det lille stedet de bodde da hun flyttet fra ham:

Den gang vurderte jeg det som det beste for barna å bli der de var, sier hun. Og jeg vet ikke om jeg hadde kunnet gjort det annerledes, for jeg var să nedbrutt, så kanskje jeg hadde gjort det samme i dag hvis jeg hadde vært der jeg var da. Jeg følte ikke at jeg hadde noen rett til å rykke dem opp med rota og ta dem med. Og jeg var innstilt på at vi var to likestilte foreldre.

Han eide småbruket de bodde på, og hun hadde mistet jobben i bygda og regnet ikke med å kunne få noen ny. Hun flyttet da på hybel i en større by:

For å få en jobb og tjene mest mulig penger så jeg kunne betale mest mulig bidrag. - Og det var ikke noe fett, med de gamle bidragsreglene, nå har jeg vært på begge sider av dette, og det var virkelig urettferdig, jeg hadde ingenting igjen, og det var helt umulig å etablere seg på nytt.

\section{Side 269:}

Hun hadde heller ikke fått med seg noe av boet. Det første halve året reiste hun hjem til barna hver uke. Da hadde alt av husarbeid samlet seg, og hun vasket hus og klær og handlet og stelte klærne til barna. «De skulle ikke mâtte gå skitne og hullete.» I ettertid sier hun: «Tenk alt hva en gjør og hva en finner seg i!» Etterhvert fant hun ut at hun ikke kunne fortsette med dette. Hun hadde heller ikke råd til å reise så ofte, for det er ganske langt. Hun hadde samvær annen hver uke, enten ved at barna kom til henne eller at hun var sammen med dem hos en venninne på hjemplassen. Barna ringte mye og ba om hjelp til lekser og andre ting, som pakking av sekk når de skulle på tur, og fordi de var alene hjemme og var redde og ikke vissste hvor pappa var. Han var mye ute om kveldene i forbindelse med jobber og fritidsaktiviteter.

Hun ble stadig mer bekymret for barna, blant annet skolegangen, der det begynte å vise seg at flere av barna lå langt etter $\mathrm{i}$ skolearbeidet. De gjorde ikke lekser, faren hjalp dem ikke og de ringte stadig til henne lenge etter leggetid for å få hjelp.

Hun nrøvde etter heste evne å tette det hun onnfattet som hullene i 
fars omsorg, både ved å hjelpe barna med det mest nødvendige over telefon, og ved å prøve å sette dem istand til å bli mest mulig selvhjulpne, for eksempel når det gjaldt kroppspleie og klesskift. «Sånn som a vaske seg og skifte underbukse hver dag, det var ingen selvfølge.» «Jeg drev fjernomsorg», sier hun i dag. Hun hjalp dem også økonomisk utover bidraget, fordi faren ofte ikke kjøpte klær eller andre ting de trengte. For eksempel betaler hun mobiltelefon for jentene, fordi farens telefon har blitt stengt av.

Datteren på 13 fikk et stadig større ansvar for å ivareta daglige behov både for seg selv og søsknene. Hun var bekymret for hvordan det gikk utover de minste barna når de måtte klare seg selv, og det utviklet seg interne hierarkier dem imellom som ingen voksen hjalp dem å megle eller rydde opp i. Hun kunne ringe og i bakgrunnen hørte hun krangel som eskalerte og stoler som gikk i gulvet:

Det er klart at hun på 13 ikke klarer det når hun for eksempel skal legge de to minste guttene, og så blir hun sint på dem.

Det var heller ingen faste måltider, og barna fikk ta det de ville, noe som resulterte $i$ at den ene sønnen levde nesten bare på kalde pølser, sjokodrikk og lomper med sjokopålegg. Han utviklet alvorlige adferdsproblemer, og ifølge skolen lå han det meste av tiden under pulten. De mente han hadde ADHD, men det har siden blitt avkreftet. Ellen mener årsaken var omsorgssvikt, i form av manglende oppfølging og rutiner, dårlig kosthold og mangel på søvn hjemme hos far.

Hun tok kontakt med skolen og barnevernet, og det ble iverksatt flere tiltak. Den ene gutten fikk leksehjelp på skolen, en hjemkonsulent fra barnevernet kom hjem flere ganger i uken, og sosialkontoret tilbød ytterligere hjelp og avlastning til far. Det var hun

\section{Side 270:}

alene som holdt kontakten med hjelpeapparatet og krevde at det ble satt inn tiltak, både i forhold til barna enkeltvis på skolen, og i forhold til hjemmesituasjonen hos far.

Mors forhold til hjelpeapparatet er dobbelt; dels har hun blitt hørt og både skole og barnevern har handlet på hennes initiativ og iverksatt tildels omfattende hjelpetiltak. Likevel opplever hun at de har liten tiltro til henne og at de ikke gjerne vil gi henne rett:

De tenker kanskje at hvis jeg får medhold i at barna ikke har det bra så vil jeg bruke det for å få omsorgen.

Selv om hun blir hørt i praksis, er også hjelpeapparatet mer eller mindre fiendtlig til henne. Dette får paradoksale utslag: Hun ba om at BUP kom inn i bildet, men de tilskrev barnas problemer konflikten mellom foreldrene, ikke den omsorgssvikt i det daglige som mor mener de blir utsatt for, og som barnevernet i praksis har tatt på alvor ved å sette inn støttetiltak i hjemmet. Ifølge mor hadde hun ikke noen konflikt med eksmannen, tvert om, han har oppfattet henne som både snill og hjelpsom. Uten nærmere begrunnelse foreslår BUP overfor barnevernet at mor skal miste foreldreansvaret. Rarnevernet vil se det an (det vil si. de avviser det 
ikke). Hun opplever seg som prisgitt barnevernet, og føler ikke at hun kan ta opp hverken dette eller andre ting med dem.

Forholdet til skole og hjelpeapparat er også preget av at det er et lite lokalsamfunn, og eksmannen får mye sympati for at han ble alene med fire barn da hun dro. Alle synes veldig synd på ham, og hun opplever at de ser på henne som en dårlig mor, og bygda, inkludert hjelpeapparatet, står sammen om hans versjon av historien. Konflikten făr også en by-land-dimensjon, da mange av aktørene, både i skole og hjelpeapparat ser det som en egenverdi å bli i bygda. Faren har også skremt barna med at det er farlig i byen, og barna var redde for à være hos henne, selv om hun bor en times kjøring fra byen - på det som for byfolk oppleves som tjukkeste bondelandet.

Første gang hun gikk til rettssak, måtte hun gi opp og inngikk et forlik etter en sakkyndigrapport som ensidig la farens versjon til grunn og en rekke uheldige omstendigheter. Blant annet ble barnevernets rapport ikke fremlagt i retten. Dette ble av bygda oppfattet som at hun tapte. Hun har nå fătt omsorgen for de to yngste barna etter ny rettssak. Den sakkyndige denne gangen konkluderer med at mannen er psykisk syk, og at det er hun som har best omsorgsevne, og at det vil være best for barna å bo hos henne. Flere av vitnene fra hjelpeapparatet trakk imidlertid utsagn de hadde kommet med i sakkyndigrapporten, og barnevernets rapport ble heller ikke denne gangen fremlagt. Begge gangene skal det ha skyldtes tekniske problemer med kommunenes dataanlegg, som hun stiller seg noe tvilende til. Personer i hjelpeapparatet var heller ikke villige til å stå ved utsagn de hadde kommet med til sakkyndig.

\section{Side 271:}

Hun fikk likevel ikke daglig omsorg for de to eldste barna - døtrene på 11 og 13, da den eldste hadde sagt at hun ville bo hos far. Begrunnelsen for dommen er dels at den eldste ville bo hos far, dels at det ville bli trist for henne om søsteren flyttet, og dels at retten frykter fars reaksjon om han mister alle barna. Ellen oppfatter dette som tvilsomme og meget problematiske begrunnelser. Hvor er barnas beste? Sosialkontoret vil imidlertid nå gå inn og vurdere mannens omsorgsevne.

Barna var hos henne på ferie da dommen falt (det ble også fattet hastevedtak frem til dommen ble rettskraftig), og hun beholdt da guttene, som begynte på skolen hos henne da ferien var slutt. Jentene måtte hun sende tilbake til far.

Guttene skulle på intervjutidspunktet snart til far på samvær, og hun fryktet for hva han kunne finne på. Hun var redd ham, og tenkte blant annet på våpen:

Han lever i en boble, langt fra virkeligheten, han skjønner for eksempel ikke hvorfor han har en fra sosialkontoret som kommer hjem til dem flere ganger i uka, og sakkyndig sa også at hun lurte på om han hadde skjønt det som var vedtatt. Når det går opp for ham og boblen brister, hva gjør han da?

Hun er også redd for at han ikke leverer dem tilbake etter samvær: 
Det har han gjort før, beholdt en unge for en annen far i familien.

Fordi hun er redd for eksmannen og for at det kan bli ubehagelig for barna om hun følger dem til ham, har hun bedt om at noen fra sosialkontoret/barnevernet kunne følge dem til far og hente dem der, også for at han skal vite at de vet at han har dem på samvær. Men det ville de ikke, og begrunnet det med at de ikke jobbet i helgene, til tross for at hun vet de har sagt til far at de kan stille opp også i helgene for å avlaste ham.

Også hun har forsøkt å bidra til at barna får et godt bilde av far til tross for at hun opplever at hans omsorg for barna er utilstrekkelig. Barna opplevde for eksempel at de ikke kunne snakke om mor hjemme, og hun har forsøkt å gi barna inntrykk av at de kan snakke sammen. Blant annet ringte hun til eksmannen og førte bevisst «normale» samtaler om vær og vind og tok ikke opp konflikter, for at barna skulle oppleve at mor og far kunne snakke normalt sammen. Tanken var at når han la på og de spurte hvem han hadde snakket med så kunne han si «mor», og hun tenkte det ville være fint for barna at de hørte at de kunne snakke normalt sammen. Hun avtalte også med hjemkonsulenten at hun skulle snakke med barna om mor så far hørte det for at det skulle bli lov for dem å snakke om henne hjemme:

Og da snakket de som en foss.

\section{Side 272:}

\section{Felles for de to}

\subsection{To likeverdige foreldre?}

Britts forsøk på å forklare problemene i samlivet ble i liten grad tatt på alvor i familierådgivning, og ble avvist av retten som irrelevante. Det blir paradoksalt når moren forlater faren av årsaker som helt klart er relevant i forhold til ham som omsorgsperson at de så blir møtt både i hjelpeapparatet og i retten som to likeverdige foreldre, hvor disse problemene ikke ses som relevante. Britt opplevde at det ikke var en reell vurdering av situasjonen som lå til grunn for rettsavgjørelser, men mer ytre vurderinger av hvor barna har bodd og at hun har vært hjemme med dem.

Ellen forlot mannen på grunn av at han ikke fungerte som medforelder til felles barn. Likevel følte hun at hun ikke hadde rett til å ta barna med seg ut av sitt vante miljø. Hun så altså miljøet som viktigere for barna enn seg selv som mor, til tross for at hun hadde vært den viktigste omsorgspersonen for dem. Til tross for at farens manglende engasjement og prioritering av barna bidro til at hun forlot ham, så hun det slik at de var to likeverdige foreldre, og at det derfor var best for barna å bli hos ham. Ellens sak må forstås i lys av at hun var svært nedkjørt og kanskje heller ikke så andre muligheter. Likevel illustrerer hennes resonnement omkring dette både hvor liten betydning mødrene tillegges og hvor stor velvilje som blir fedrene til del som likeverdige foreldre, selv der den konkrete far ikke har levd opp til kravene.

Begge opplever at det tas mer hensyn til far enn til barna, og begge refererer til farsdiskırsen snm nne snm har slått inn i deres saker. 
Hos Britt blant annet gjennom at faren deltar aktivt i ulike fedrefora og i media, for Ellen ved at sakkyndig den første gangen var sterkt ideologisk preget av sin overbevisning om behovet for far, og entydig la frem saken fra fars side. I tillegg oppfatter begge at den allmenne meningsdannelsen går sterkt i fars retning. Ellen sier at hun selv også har ment veldig sterkt at far er like god som mor, og hun har også forståelse for bidragsfedrenes krav etter selv å ha vært i denne situasjonen. I forholdet til egne barn har begge til en viss grad internalisert farsdiskursens retorikk - noe som fremgår av Ellens resonnement og som også Britt gir uttrykk for. Selv om hun ikke har noen positive eksempler på at eksmannen er en god far, men at hun tvert om er svært bekymret over mange ting han gjør, starter hun likevel med å si at han både er en god og en dårlig far. Hun mener også at barna bør ha kontakt med faren sin.

Farsdiskursen trer frem i begge intervjuene, på en dobbel måte. Dels blir farsdiskursen en ytre faktor og en samfunnsmessig rammebetingelse som har påvirket og preget måten mødrene har blitt møtt og forstått på i hjelpeapparat og rettsvesen. Dels har de internalisert forestillingen om to likeverdige foreldre og barnas behov for far, til tross for konkrete erfaringer med at far ikke fun-

\section{Side 273:}

gerer som forelder, eller at far gjør ting som er i konflikt med god omsorg. Likevel fastholdes en retorikk om likeverdig foreldreskap og barns behov for far, der den konkrete farens mangler forsvinner, mens den mer ideologisk begrunnede, overordnede farsdiskursen blir en begrunnelse i seg selv. Dette er i tråd med det Haugli finner i saker for Lagmannsretten, der felles foreldreansvar tas for gitt utfra et ideologisk standpunkt som det ikke stilles spørsmål ved. ${ }^{29}$

\subsection{Mor kompenserer for mangelfull omsorg hos far} Mødrene strekker seg langt for å ivareta barna og dekke opp for mangler ved fars omsorg eller hjelpe barna for å bearbeide opplevelser hos far. Begge har også strukket seg langt for å ivareta barnas relasjon til far og barnas bilde av far. Motsatt synes fedrene à fremstille mødrene negativt overfor barna, og også dette må mødrene hjelpe barna å bearbeide. Mødrene utfører følgelig et betydelig emosjonelt arbeid, både med å holde sine egne dårlige erfaringer med eksmannen skilt fra barnas relasjon, samt å hjelpe

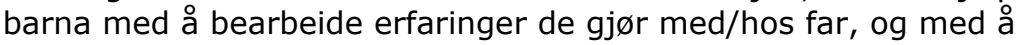
bearbeide barnas opplevelse av at far trekker dem inn i hans konflikt med mor. Når mødrene kompenserer for både konkrete og relasjonelle mangler ved fars omsorg, fører dette også til at mangler ved fars omsorg og relasjon til barna blir mildnet og usynliggjort. Elvin-Nowak viser at usynliggjøring av mors merarbeid og meransvar inngår i det likestilte foreldreskapet innen parforholdet, og at mødre selv tar ansvaret for å forstørre fars og forminske egen innsats i likestillingens navn. ${ }^{30}$ Også Bekkengen diskuterer dette som hun kaller «verdsettingens paradoks». ${ }^{31}$ Så lenge dette skjer innenfor parforholdet, vil konsekvensene ikke nødvendigvis bli så store. Ved samlivsbrudd og etter samlivsbrudd, kan imidlertid det usynlige morsarbeidet føre til at mor făr problemer med å bevise at det er problemer overfor hjelpeappparat og rettsvesen, og hun kan oppleve ikke å bli trodd. Videre kan usynliggjøringen av mødres større arbeid og ansvar føre til at man på feilaktig grunnlag ser foreldre som likeverdige omsorgspersoner. 


\subsection{Vold også der det ikke er vold}

Vold har ikke vært tematisert overfor hjelpeapparat i noen av disse sakene, og ingen av dem har nevnt vold i forbindelse med rettssakene. Likevel viser det seg å være vold inne i bildet. Ellen har opplevd to tilfeller med fysisk vold fra eksmannen. Britt har ikke selv opplevd vold, men mannen var voldelig mot hennes mor da han kidnappet det ene barnet, og hun politianmeldte ham. Hun

29. Haugli 2004 s. 356.

30. Elvin-Nowak 2001

31. Bekkengen 2002.

Side 274:

sier selv at det ikke var vold inne i bildet i deres samliv, men kommer likevel inn på en nylig avsluttet rettssak som har vært omtalt i media, der mannen ble dømt for å ha drept sin ekskone etter å ha ført en rekke rettssaker mot henne. Hun ser paralleller og sammenligner sin egen erfaring med gjentatte rettssaker om «tulleting» og mannens karaktertrekk, med drapsmannens, men hun opplever ikke selv at mannen kan være farlig. På spørsmål om hun er redd, er hun mest opptatt av de psykiske skadevirkningene han påfører barna. Ellen er også opptatt av de psykiske skadevirkningene. Hun frykter mannen og er redd for hva han kan finne på når det går opp for ham at han ikke lenger skal ha daglig omsorg for to av barna. Hun har vært redd han skal komme og dra barna inn i bilen på skoleveien, og hun sier at han har våpen.

Begge har oppplevd at mannen har satt dem i en avmaktsposisjon overfor barna: Ellen ved å bli utsatt for vold mens barna så på, Britt ved at mannen låste sønnen inne på rommet sitt og gjemte nøkkelen selv om hun gråt og ba. Spørsmålet er om ikke også Britts eksmanns ekstreme aggressivitet og kontrollbehov må forstås innenfor et voldsspekter. Dersom vi bruker begrensning av livsrommet som målestokk er det klart at begge har erfaringer som må forstås slik. Det at ingen av dem ville blitt synlige om man bare gikk etter den fysiske volden, eventuelt den volden de rapporterte til hjelpeapparat eller i retten, tilsier at man trenger et mer konsekvensrettet fokus som tar hensyn til omsorgsforeldrerens totale livssituasjon.

I et temanummer om vold, foreldreansvar og samvær dokumenterer samtlige artikler i tidsskriftet Violence against women 32 at den rettslige oppfølgingen, forståelsen og beskyttelsen av kvinner og barn i saker med partnervold er svak i rettsapparatet: Johnson et al. fant at vold i stor grad blir oversett i megling. ${ }^{33}$ Kernic et al. fant at vold ikke ble identifisert selv i saker med dokumenterte og betydelige innslag av vold, og at selv der voldshistorien var kjent, ble det sjelden iverksatt sterke beskyttelsestiltak. ${ }^{34} \mathrm{O}^{\prime}$ Sullivan fant at fedre trakk saker om foreldreansvar når mødrene trakk anklager om vold, og at mødre hadde større sjanse å få daglig omsorg om de trakk tilbake voldsanklager mot ekspartner. ${ }^{35}$ Sullivan peker på at dette mønsteret har negative konsekvenser for kvinner som er sårbare for press og trusler fra voldelige ekspartnere.

\subsection{Blir ikke tatt på alvor}


Begge informanter opplever at mannen har alvorlige psykiske problemer, og at dette ikke blir tatt alvorlig og håndtert skikkelig

32. Violence Against Women, 2005 Vol. 11, No. 8.

33. Johnson et al. 2005.

34. Kernic et al. 2005.

35. O'Sullivan 2005.

Side 275:

innenfor hjelpeapparat og rettsvesen. Et problem er konsensusorienteringen som forutsetter likeverdige foreldre som er $\mathrm{i}$ stand til å snakke fornuftig sammen og handle utfra barnets beste. I saker som disse, der det ikke er mulig å føre en slik normal dialog, fungerer forestillingen om konsensus og likeverd som en ekstra byrde for mødrene, som opplever ikke å bli tatt på alvor. Møtet med både hjelpeapparat og rettsvesen har begge opplevd som

krenkende og begge har opplevd vilkårlig og overfladisk behandling i retten. Haugli problematiserer også enighetsideologien i forhold til saker der det er store konflikter mellom foreldrene. ${ }^{36}$

Til tross for opplevelsen av ikke å ha blitt tatt på alvor av hjelpeapparat og rettsvesen, har mødrene (om enn i noe ulik grad) fătt gjennomslag, noe som tyder på at deres forståelse av situasjonen og barnets beste likevel må ha blitt tillagt vekt i praksis. Slik kan kanskje den dels avvisende, dels overfladiske holdningen som mødrene opplevde at de ble møtt med i hjelpeapparat og i retten være en form for tributt til forestillingen om likeverdige foreldre og farsdiskursen - mødrene skal ikke ta for gitt at de får støtte - selv om de i praksis i en viss utstrekning får gjennomslag.

Selv om mødrene (delvis) har fătt gjennomslag i forhold til daglig omsorg og avtaler om samvær, er det ingen instans som vil hjelpe dem å håndheve avtaler dersom mannen tar seg til rette og ikke følger opp det som er avtalt. Her ønsket begge seg at sosialkontoret/barnevernet skulle ta ansvar, men fikk ikke gehør. Det blir dermed mor som må hente barn etter samvær, der mannen for eksempel beholder barna, og ikke leverer dem i henhold til avtalen. Dette synes å være en urimelig byrde å pålegge den som har daglig omsorg, og det ville lette deres situasjon og muligens redusere konfliktnivået om ansvaret for å håndheve avtaler i praksis lå hos en utenforliggende og nøytral instans.

\subsection{Handlingsrom og livsrom}

Mødrene har lykkes i å fă gjennomslag når de selv har tatt initiativ overfor rettvesen/hjelpeapparat, og må dermed sies å ha hatt et visst handlingsrom. Likevel deler begge en opplevelse av avmakt ved at deres forståelse av situasjonen tillegges liten vekt. Britts liv styres av rettssakene mannen stadig trekker henne inn i. Det făr store konsekvenser, både for hennes økonomi og for hennes bruk av tid og krefter. For Ellens del krever det mye tid og krefter at hun må drive fjernomsorg overfor barna og være pådriver overfor hjelpeapparatet for à kompensere for manglene ved mannens omsorg. Begge mødrene bærer en uforholdsmessig del av forsørgeransvaret, noe som begrenser deres økonomiske handlingsrom. 
Ellen frykter mannen og er redd farlige situasjoner kan oppstå når barna skal til og fra samvær. Også Britt bekymrer seg over

36. Haugli 2004: 353.

Side 276:

situasjoner som oppstår der mannen tar seg til rette. Hun frykter de psykiske konsekvensene for barna av at han bruker dem i konflikten. Begge må sies å ha fått sitt handlings- og livsrom begrenset i betydelig grad.

Ellen vil forsøke å få til sjeldnere samvær, utfra behovet for å få barna, som har lidd under fars omsorgssvikt, på rett kjøl. Britt vil som siste utvei kreve at samværet stoppes dersom han ikke følger avtalene. Dette er etter at far gjentatte ganger har tatt seg til rette og ikke følger avtaler når det gjelder henting og levering av barn, Ingen av disse fedrene er mistenkt for vold eller overgrep. Britts eksmann påvirker imidlertid barna og trekker dem inn i konflikten, mens Ellens eksmann ikke er i stand til å gi barna den omsorgen $i$ det daglige som de har behov for. Det er likevel et åpent spørsmål om de vil nå frem med å få begrenset eller stanset samvær, selv om det vedtas en presisering av barneloven der barnets beste skal gå foran samværsretten.

For Britts vedkommende er relasjonen til eksmannen, hans trenering av levering etter samvær og gjentatte rettssaker en stor belastning. Men hittil er det hun, og ikke så mye barna som har lidd under dette, som følge av at hun har forsøkt à skjerme barna. Det er dermed ikke sikkert at hun ville fă medhold i at samvær er i strid med barnas beste. At hun selv sliter med både å skulle fungere som hovedfors $ø$ rger og hovedomsorgsperson, mens mannen stadig trekker henne inn i nye og belastende situasjoner som truer hennes helse, har ikke vært tema. Hva som kan gjøres for å beskytte mor og sørge for at mor fortsatt fungerer er det i dag tenkt lite om, og det synes ikke å være grunnlag for å hindre den ene part i å trekke den andre inn i stadig nye og utmattende rettssaker. En interessant høyesterettsdom nevner imidlertid hensynet til å ivareta moren som omsorgsperson, og til ikke å pålegge henne et belastende samarbeid med far i en situasjon med høyt konfliktnivå. ${ }^{37}$ Denne saken gjaldt imidlertid et barn som var spesielt sårbart på grunn av autisme. Ut fra vårt materiale synes det som om hensynet til ̊̊ ivareta mor som den fungerende forelderen, ikke er noe viktig moment, hverken i hjelpeapparat eller rettsvesen.

Britt ønsker seg at retten til gjenopptakelse av rettssaker begrenses. Samtidig opplevde Ellen at hun først fikk omsorgen for to av barna etter en gjenopptakelsessak. Mens Britts eksmann har lykkes i å få saken opp igjen og igjen, opplevde Ellen at hun i første omgang ble avvist.

En forsiktig konklusjon som kan trekkes utfra dette begrensede materialet er at det kan synes som om rettsvesenet er mer lydhøre for de krenkede fedrene enn for bekymrede mødre. Videre at kravene til en god far er lavere enn kravene til en god mor.

37. Rt. 2003 s. 35. 


\section{Litteratur}

Barne- og familiedepartementet (2004): Vold - rapport fra en interdepartemental arbeidsgruppe.

Bekkengen, Lisbeth, (2002): Man får välja - om föreldraskap och föräldraledighet i arbetsliv och familjeliv. Malmø: Liber.

Boyd, Susan B. (2004): «Demonizing mothers: Fathers' rights discourses in child custody law reform processes», i Journal of the association for research on mothering. Spring/summer 2004, vol 6, No. 1 pp. 52-75.

Elvin-Nowak, Ylva (2001): I sällskap med skulden - om den moderna mammans vardag. Stockholm: Albert Bonniers förlag.

Eriksson, Maria (2002): «Pappors våld och det svenska jämställdhetsprosjektet - om kön, separationer och skydd av barn.» Paper presentert på konferansen Subjekt, politik och könskonstruktioner: Det jämställda Norden som framtidsverkstad. Stockholm, den 28.02.2002. NIKK, småskrifter nr. 8, 2002.

Eriksson, Maria (2003): I skuggan av Pappa - familjerätten och hanteringen av pappors våld. Doktorgradsavhandling, Uppsala universitet. Stehag: Gondolin.

Haugli, Trude (2004): «Til barnets beste. Familiebilder $i$ endring», $i$ Kirke og kultur nr. 3.

Hester, Marianne (2002) Two steps forward and three steps back? «Children, abuse and parental access in Denmark». Nordisk ministerråd: TemaNord 2002: 545.

Johnson, Nancy E., Dennis P. Saccuzzo og Wendy J. Koen (2005): «Child Custody Mediation in Cases of Domestic Violence Empirical Evidence of a Failure to Protect», i Violence Against Women, Vol. 11, No. 8, pp. 1022-1053. SAGE Publications.

Kaul, Hjørdis (2001): «Hønemor og haremor. Skilte mødres ivaretakelse av egen og banas velferd», i Moxnes, Kari, Inge Kvaran, Hjørdis Kaul og Irene Levin: Skilsmissens mange ansikter: om barns og foreldres erfaringer med skilsmisse. Kristiansand: Høyskoleforlaget.

Kaul, Hjørdis (2003): «Mors lange armer», innlegg på konferanse om morskap ved UiO.

Kernic, Mary A., Daphne J. Monary-Ernsdorff, Jennifer K. Koepsell, Victoria L. Holt (2005): "Children in the Crossfire - Child Custody Determinations Among Couples With a History of Intimate Partner Violence», i Violence Against Women, Vol. 11, No. 8 pp. 991-1021. SAGE Publications.

Keskinen, Suvi (2002): «Traumatized mother and important father relations», innlegg på konferansen Subjekt, politik och könsonstruktion: det jämställda Norden som framtidsverkstad. Stockholm 28.02- 01.03.2002. NIKK, småskrifter nr. 8, 2002.

I ødrın. Peter (つחก.3) «Farskansrevolısionen». i Tidsskrift for 
familierett, arverett og barnevernsrettslige spørsmål» nr. 2.

Mellberg, Nea (2005): Moderskap och mödrar i det könsrelaterade våldets vardag. Upubl. sluttrapport til Norfa.

Nordisk ministerråd: Kön och våld. Ett nordiskt forskningsprogram. Sluttrapport. TemaNord 2005: 544.

NOU 2003: 31: Retten til et liv uten vold. Menns vold mot kvinner i nære relasjoner.

\section{Side 278:}

O'Sullivan, Chris S. (2005): "Outcomes of Custody and Visitation Petitions When Fathers Are Restrained by Protection Orders», $i$ Violence Against Women, Vol. 11, No. 8 pp. 1054-1075. SAGE Publications.

Radford, Joanna (2994) «Equality and the law of custody and access». Journal of the association for research on mothering. Spring/summer 2004, vol 6, No. 1. pp. 28-52.

Radford, Lorraine, Kaname Tsutsumi 2004): «Globalization and violence against women - Inequalities in risks, responsiblilities and blame in UK and Japan», i Women's Studies International Forum 27 (2004) 1-12.

Skjørten, Kristin: (2002): «Omsorgskampen mellom mor og far», presentasjon på konferanse, Universitetet i Oslo.

Skjørten, Kristin: (2004): «Forståelser av overgrep i barnefordelingssaker», $i$ Tidsskrift for familierett, arverett og barnevernrettslige spørsmål nr. 3-4/2004, s. 169-170.

Weisser-Aall, Lily (1973): «Omkring de nyfødtes stell i nyere norsk overlevering». Oslo: Norsk folkemuseum.

(C) Gyldendal Akademisk 